Profit: Jurnal Kajian Ekonomi dan Perbankan 2 (1) 2018. P: 62-85

PROFIT : JURNAL KAJIAN EKONOMI DAN PERBANKAN https://ejournal.unuja.ac.id/index.php/profit

E-ISSN : 2597-9434, ISSN: 26854309

\title{
GAIN INCOME DARI GAME ONLINE TINJAUAN TEORI PERTUKARAN HAK / $A K A D$ (DALAM PERSPEKTIF EKONOMI ISLAM)
}

Raden Achmad Haryo Kusumo* Abstract:

Era milenial yang ditandai dengan skema Industri 4.0, aplikatifnya adalah memasuki zaman digital. Lazimnya, sebelum manusia memasuki era digital, segala perangkat interaksi antar individu dilakukan secara manual, akan tetapi berbeda dengan dunia saat ini. Era digital menjadikan manusia memiliki "kesibukan baru", kesibukan yang sekaligus menjadi ajang bergengsi di seantero dunia saat ini; adalah game online. Game online yang masuk salah satu cabang olah raga; E_Sport, adalah satu-satunya permainan yang mampu mempertemukan antar pemain di belahan dunia secara bersama-sama (multyplayers). Berbeda dengan genre game sebelumnya, game online memiliki daya pikat tersendiri, bagi sebagian individu, game online sekedar hobi, tapi bagi individu yang lain, game online bertujuan mencari keuntungan, bahkan keuntungannya hingga milliaran rupiah. Akan tetapi menariknya, apabila kultur Islam memiliki tradisi akad dalam tiap-tiap peralihan harta kekayaan (memperoleh pendapatan), lantas bagaimana pendapatan (memperoleh kekayaan) jika dengan bermain game. Singkatnya, bagaimana hukum mendapatkan uang dari bermain game menurut Islam, apakah diperbolehkan ataukah masih ada kaidah-kaidah tertentu yang harus dipenuhi sebelum dinyatakan kebolehannya.? Tulisan ini akan mengupas kaidah memperoleh pendapatan dari bermain

- IAI Al-Khoziny Buduran Sidoarjo

Email :

raden.rio95@gmail.com game berdasar teori akad. Dengan demikian, secara akad, gain income (mendapatkan uang) dari bermain game itu dapat diketahui ke halal atau haramannya

Keyword: Game Online, Akad, Ekonomi Islam 


\section{PENDAHULUAN}

Dunia maya, atau yang penulis istilahkan dengan the seccond of world, (dunia ke dua) adalah; progress dunia yang tidak tidak dapat; disentuh, dibau, dan dirasa. Ketika dunia faktual selalu dimaknai dengan sesuatu yang dapat; dilibat, disentub, dibau, dirasa, dandidengar', maka dunia maya tidak memiliki unsur yang lengkapdengan persamaan kategori dunia yang terdiri dari lima elemen itu. Dunia maya atau dunia digital hanya memiliki dua aspek; dilihat dan didengar, selebihnya tidak ${ }^{2}$. Maka jika di cermati, resolusi dunia digital sesungguhnya bertambah sempit, jika asalnya terdiri lima sudut panca indera, dalam dunia digital hanya memiliki dua sudut panca indera. Namun demikian, tidak serta merta orang dapat mengacuhkan dunia digital yang bersudut pandang sempit itu. Justru dengan dunia digital, manuisa memiliki alternatif baru sebagai moda imajiner antar individu satu dengan yang lain ${ }^{3}$. Dan saat ini, dunia alternatif / the seccond of world lebih riil daripada dunia faktual. Banyak nilai ekonomis yang didapat dari dunia digital, antara lain; kekuasaan, ekonomi, budaya, teknologi, biologi, mekanik dan lain sebagainya, tergantung individu - individu bagaimana memanfaatkan dunia maya dalam mengakomodir kebutuhannya.

Dalam the seccond of world itu banyak view yang ditawarkan, ada game, literasi, audio video, melalui "kapling-kapling" website seperti; blogspot, wordpress, google adense dan lain-lain ${ }^{4}$, bahkan tidak hanya itu, malahan juga merambah ke mata uang digital / cryptocurrency $^{5}$. Menarik memang, apalagi jika dikiaskan dengan kehidupan faktual, ketika ada

\footnotetext{
${ }^{1}$ Kelima panca indera manusia.Termasuk teknik mengenali lingkungan atau untuk menghafal sesuatu, erat hubungannya dengan devinisi-devinisi keduaniaan yang materiil. Seperti dalam buku; Noraini Ahmad, Menguatkan Ingatan, (Selangor Dalur Ehsan, Malaysia : LOHPRINT SDN BHD, 2004) 15.

${ }^{2}$ Mirip-mirip dengan istilah sufistik, yang mendalami dunia batin. Namun keduanya sangat jauh berbeda, jika sufistik me_"room in" sehingga dunia tampak kecil dibanding batin (jagat gede), sedangkan dunia maya me_"zoom out" sehingga dunia faktual terasa lebih besar. Lihat buku; Achmad Chodjim, Syaikh Siti Jenar danMakna Kematian, (Jakarta : PT Serambi Ilmu Semesta, 2014), 177.

${ }^{3}$ Mirip-mirip dengan istilah sufistik, yang mendalami dunia batin. Namun keduanya sangat jauh berbeda, jika sufistik me_"room in" sehingga dunia tampak kecil dibanding batin (jagat gede), sedangkan dunia maya me_"room out" sehingga dunia faktual terasa lebih besar. Lihat buku; Achmad Chodjim, Syaikh Siti Jenar danMakna Kematian, (Jakarta : PT Serambi Ilmu Semesta, 2014), 177.

${ }^{4}$ Disadari atau tidak, koneksi virtual banyak mempengaruhi kondisi psikologis manusia, walau kaitannya dengan yang penulis katakan (zoom out) yang hanya dapat dilihat dan didengar. Lebih detailnya lihat buku; Rulli Nasrullah, Teori Dan Riset Media Siber (CYBERMEDIA), Cet ke II (Jakarta : Prena Media Gorup, 2016) ,148. ${ }^{5}$ Dalam buku Seri Panduan Lengkap Microsoft $W$ indows 7, Diterbitkan atas kerjasama penerbit Andi Yogyakarta dengan MADCOMS, (Yogyakarta : CV Andi Offset, 2010), 205. koneksi internet dijelaskan dengan; Membaca informasi, berkirim pesan, berkomunikasi real time (teks, voice call, video call), berbagi file, berbagi data diri hingga sarana malaporkan kegiatan yang kita lakukan (publish journal). Dan ketika mengakses homepage luar negeri, maka internet service provider lah yang menanggung biaya hubungan ke luar negeri,pengakses cukup membayar biaya pulsa lokal yang digunakan untuk menghubungi internet service provider.
} 
yang mengatakan bahwa dalam manusia hidup terdapat bulan-bulan kreasi (work/kerja) dan ada bulan-bulan rekreasi (refreshing/bersantai) ${ }^{67}$, atau ada yang menyebut bulan kreatif dan bulan rekreatif, maka sesungguhnya ketika pada bulan kreatif/kreasi (diluar mindset digital) tidak diperbolehkan untuk rekreasi ke tempat-tempat semisal pantai, pegunungan, kebunkebun dan lain sebagainya, tetapi tidak dengan apa yang terjadi pada dunia digital / seccond of world.

Game dalam dunia digital dipandang sebagai rekreasi, atau permainanimajinatif oleh para peselancar dunia maya. Maka dalam dunia digital dikotomi bulan kretif maupun rekreatif tidak berlaku, karena game dapat dimainkan kapan saja dan dimana saja. Hal ini terbukti dengan; ketika seseorang lelah, capek dengan seabrek pekerjaan, game adalah satu-satunya solusi hiburan digital yang juga mempunyai manfaat ekonomis ${ }^{7}$, tidak membutuhkan perpindahan tempat yang membutuhkan waktu, tenaga dan uang, dalam satu layar monitor antara game dengan tugas dapat dikerjakan bersama-sama, seseorang tinggal klik untuk beralih dari layar tugas ke layar game. Dengan demikian individu tidak di repotkan lagi dengan peralihan fisik yang membutuhkan tenaga, waktu, dan uang. Untuk itu game (permainan dalam dunia digital) tidak akan pernah surut, malahan akan terus bergerak dan berkembang sesuai situasi dan kondisi zaman.

Ketika game dapat dijadikan mendulang uang, dari beberpa permainan yang ditawarkan, lantas bagaimana hukum mendulang uang dari bermain game dalam tradisi Islam.? Uang yang diperoleh termasuk sah apa tidak.?

Disini akan penulis lihat dari pendekatan teori pertukaran hak, atau dalam tradisi Islam disebut al-'aqd / akad. Sebelum bembahasan lebih lanjut, ada baiknya dalam bab ini penulis bahas sedikit tentang pengertian akad, dan akan dikupas lebih jauh di bab selanjutnya. Pada intinya, tulisan ini berusaha membuka unsur-unsur apa yang mesti dihindari dalam proses peralihan hak (mendapatkan uang dari game), sekaligus untuk menjawab sah atau tidaknya uang yang diperoleh darinya.

\footnotetext{
${ }^{6}$ Tentang mata uang digital lihat buku; Dimaz Ankaa Wijaya, Mengengal Bitcoin dan Cryptocurrency, (Medan : Puspantara Jalan Abadi, 2016), 10. Baca juga bukunya; Brian Kelly, The Bitcoin Big Bang How AleternativeCurriencies Are About to Change the World, Terj oleh Andri, The Bitcoin Big Bang, Bagaimana Mata UangAlternatif Mengubah Dunia, (Jakarta : PT Elex Media Komputindo, Gramedia, 2018), 168., ${ }^{7}$ Seperti yang ada dalam buku; Yuliandi Kusuma, Panduan Kreatif Fotografi Travel, (Jakarta : PT Grasindo, 2010), 12. Disitu dijelaskan jika ingin memotret kota New York yang penuh pemandangan geudng-gedung dan neon sign berwarna warni mengunjunginya pada bulan November Desember bukanlah momen yang tepatkaerna New York mengalami musim dingin. Maka jika bermaksud demikian sebaiknya mengunjungi New York pada bulan Juni hingga Agustus.
} 
Akad adalah akomodasi pertukaran hak milik antara individu satu derhadap individu yang lain. Dalam tradisi keislaman, peralihan hak dari individu satu terhadap yang lain jika tanpa menggunakan akad yang jelas, maka peralihan hak itu dapat menjadi batal / fasid. Seperti contoh; ketia uang 100.000,- yang asalnya dimiliki tuan A, kemudian berpindah ke tuan B, dalam hukum ekonomi Islam harus ada akadnya seperti; Pemberian (sedekah, infak, zakat) atau sebagai laba dari penjualan, atau uang 100.000,- itu sebagai akad persekutuan. Oleh karenanya harus ada akad terlebih dahulu. Tinjauan akad setidaknya terbagi menjadi dua; yakni terkait rukun dan syarat ${ }^{8}$.

11 Rukun akad;

Pernyataan untuk mengikatkan diri (sighat al-'aqd)

Pihak-pihak yang ber-akad (al-muta'aqidain)

Objek akad (al-ma'qud alaibi)

12 Syarat akad; mengacu kepada pendapat Ibnu Taimaiyyah ${ }^{9}$ bahwa akad hendaknya dibuat secara sukarela / tanpa paksaan dari pihak manapun, maka akad yang ada unsur paksaan, akadnya manjadi tidak sah. Implementasinya pada bisnis yang bersekutu (syarikah/persekutuan) rukun akad itu harus ada pada ${ }^{10}$;

Syirkah abdan; adalah persekutuan antar tenaga ahli. Jadi persekutuan / syirkab ini bukan seperti pemilik modal dan pengelola, tapi perserikatan antar keahlian bidang masing-masing, jumlahnya bisa dua orang atau lebih. Semisal; seseorang yang ahli di bidang arsitektur bangunan, medis, dan IT (Informatika) bekerja sama menjalin suatu ikatan kerja dengan tujuan mendirikan proyek rumah sakit.

2. Syirkah inan; adalah persekutuan antar kedua (atau lebih) orang / badanhukum yang masing-masing memberikan modal uang sebagai perikatan.. Perbedaan dengan abdan adalah; syirkah inan mensyaratkan suatu modal keuangan, untuk jenis-jenis pekerjaan masing-masing subjek persekutuan tidak terikat, dengan kata lain tergantung kesepakatan. Jika ada benda materi yang di akad_kan untuk

${ }^{8}$ Salah satu manfaat selain materi dari bermain game adalah mengenal dunia komputer dan internet lebih dekat. Banyak ahli-ahli pemrograman komputer yang dulunya adalah penghobi game. Dan saat ini mereka para penghobi game itu direkrut perusahaan-perusahaan besar untuk membuat program komputer. Selebihnya lihat buku; Rendi Santoso, 10 Tahun Lagi Lo Mau Jadi Apa.?, (Jakarta : Elex Media Komputindo, Gramedia, 2014), Hasballah Thaib, Hukum Akad dlam Fikih Islam dan Praktek di Bank Sistem Syariah, (Medan : Program Pascaasarjana Universitas Sumatera Utara, 2005), 4.

'Ibnu Taimiyyah, Majmu' Fatawa, Jilid 28, (Saudi Arabia, 1938), 77.

${ }^{10}$ Hasan Ayyub, Fikih Al-Mu'amalat Al-Maliyyah fi Al-Islam, (Kairo: Dar As-Salam, 2006), 225. 
syirkah ini tapi bukan berbentuk uang, maka benda tersebut harus di hitung berdasar nilai uang yang berlaku saat akad.

3. Syirkah wujuh; adalah persekutuan reputasi. Nama baik seseorang dipertaruhakan dalam suatu ikatan jual beli. Semisal seseorang yang memiliki nama baik di hadapan publik (Guru besar / Kyai / yang lain) berserikat dengan suatu badan hukum (PT / CV / UD dan lain-lain) untuk membangun suatu proyek komoditi tertentu. Jadi intinya, ber_syirkahwujuah ialah; persukutuan yang mengikatkan diri dengan ketokohansesorang.

4. Syirkah modhorobah; adalah persekutuan antar kedua belah pihak, yangsatu memberikan modal, sedangkan yang lain sebagai pengelola. Syirkabmodhorobah banyak macamnya, ada mutlaqah, muqayyadah, dan lain-lain.Akan tetapi untuk menjaga agar pembahasan tetap terfokus pada sub judul, oleh karenanya hanya di bahas syirkah mudhorobah secara singkat.

5. Syirkah mufawadhah; adalah persekutuan yang mengakomodir ke empatjenis persekutuan seperti yang telah dijelaskan sebelumnya. Jika rukun dan syarat ke empat jenis persekutuan diatas telah dilaksanakan sesuai ketentuannya, maka syirkah mufawadhah sah untuk di laksanakan.

Disamping ke lima teori persekutuan diatas, ada lima pijakan dasar yang ditekankan dalam aktifitas akad, seperti yang penulis ambil dari terminologi perbankan syariah, dalam bukunya Prof Ismail Nawawi ${ }^{11}$, dikatakan dengan;

a. Terbebas dari unsur riba

b. Terhindar dari unsur gharar

c. Terhindar dari unsur judi

d. Terhindar dari unsur haram

e. Terhindar dari unsur syubhat (sesuatu yang tercampur antara yang halal dan yang haram)

Akad dalam pengertian bahasa Arab adalah Al-'aqd yang berarti perikatan, perjanjian, persetujuan dan permufakatan.Kata ini juga bisa diartikan dengan Ar-rabtu yang menghubungkan atau yang mengkaitkan, atau mengikat beberapa ujungsesuatu. Allah berfirman dalam Al-Qur'an surat Al-Maidah ayat 1 ; artinya; "Hai orang-orang yang beriman,

${ }^{11}$ Tentu hal ini bukan berarti "orang” sebagai person/individu saja, dapat pula berbentuk PT atau CV, suatu kelompok yang berbadan hukum.Semisal; antar PT_A, PT_B dan PT_C. 
penubilah akad akad itu". Dalam terjemah"12 dikatakan; al-'aqd / akad (perjanjian) mencakup; Janji prasetia hamba kepada Allah dan perjanjian yang dibuat oleh manusia dalam pergaulan sesamanya.

\section{MENDAPATKAN UANG DARI GAME}

\section{A. Pendapatan Pengembang / Developer Game}

Ada banyak model yang ditawarkan game (permainan dalam dunia digital) untuk mendapatkan uang, molai dengan ribuan bahkan hingga milliaran rupiah. Bentuk-bentuk game nya, ada yang online ada yang offline, dan hampir kesemuanya melibatkan transaksi keuangan. Namun tidak semua transaksi keuangan dalam game dapat mendulang rupiah dari pemainnya. Ada yang hanya owner / pemilik saja yang dapat memanen uang dari game ciptaannya.

Seperti game offline yang fenomenal / sempat viral karena pendapatan dari produksinya yang sangat-sangat fantastis; Flappy Bird ${ }^{13}$, dengan pendapatannya 50.000 USD per hari atau skitar 600 juta rupiah. Flappy Bird adalah game gratis yang mengandalkan metode in-app ads ${ }^{14}$, bukan in-app purchase yang mengharuskan pengguna membeli untuk mengakses fitur tertentu, iklan yang ditampilkan pun tidak mengganggu atau mengurangi pengalaman bermain. Namun Flappy Bird, game besutan Nguyen pemuda asal vietnam tersebut tidak bertahan lama setelah meraih predikat game terlaris. Bahkan saat ini, game yang dirilis sekitar akhir tahun 2012 akhir sampai dengan 2013 akhir itu dikabarkan game tersebut telah ditarik dari peredaran karena beberapa hal ${ }^{15}$, diantaranya; mencontek, tak tahan kritik, sebagai taktik pemasaran dan lain sebagainya.

Ada pula game yang juga tak kalah sukses yang pernah dirilis oleh developer; Candy Crush Saga.Game besutan KING oleh Riccardo Zacconi tersebut telah meraup

\footnotetext{
${ }^{12}$ Ismail Nawawi, Perbankan Syari'ah (Issu-issu Manajemen Fiqh Mu'amalah Pengkayaan Teori MenujuPraktik, (Surabaya : Vivpress, 2011), $171 \mathrm{~s} / \mathrm{d} 192$.

${ }^{13} \mathrm{Al}-\mathrm{Qur}$ 'an dan terjemahnya, Wakaf dari Pelayan dua tanah Suci, Raja Fahd bin Abdul Aziz Al-Su'ud, Surat Al-Maidah ayat 1, hlm 156.

14https://tekno.kompas.com/read/2014/02/06/1133198/Wow.Pembuat.Flappy.Bird.Raup.Rp.600.Juta.Seha ri

15Sederhananya; In-app ads adalah sistem digital yang dimana developer hanya memanfaatkan iklan dari pihak ke tiga game nya. Jadi pemasukan yang diperoleh murni dari iklan bukan dari pembayaran para pemain, lihat juga; https://www.smaato.com/guide-to-in-app-advertising/. Berbeda dengan in-app purchase, developer game membuat sistem berbayar pada level-level tertentu yang digunakan pemain demi meneruskan / mengembangkan permainan itu, seperti agar tidak kalah dengan musuh, pemain diharuskan membeli amunisi, atau ketika stok darah berkurang, pemain diharuskan membeli produk tertentu untuk mengisi kekurangan darah, lihat juga ; https://teknojurnal.com/apa-itu-in-app-purchase/
} 
keuntungan predikat top pada kuartal III tahun 2017 lalu yang mencapai 3,3 Triliun ${ }^{16}$. Perusahaan pengembang game Candy Crush Saga; King, juga pernah di taksir dengan harga 80 Triliun pada tahun 2014 lalu ${ }^{17}$. Bandingkan dengan perusahaan start up gojek yang memiliki valuasi $^{18}$ hanya sekitar 39,98 Triliun $^{19}$.

\section{B. Pendapatan Pemain}

Setelah mengetahui pendapatan pengembang dari game yang dirilis, terkait in-app ads, kemudian bagaimana dengan pemain.? Developer game juga melihat sisi ituuntuk bagaimana mengembangkan game-game besutannya dikemudian, sebab bagi produsen seperti KING dan Flappy Bird dan pengembang-pengembang yang lain, tidak mungkin membiarkan pengguna game yang demikian banyaknya, sanga pemain player hanya sebagai pemain pasif. Pengembang juga mendesain supaya genre game tersebut dapat menjadi kreatif (memiliki sisi ekonomis) dari pemakai, sehingga pemakai sebagai consumer sekaligus dapat memperoleh keuntungannya. Berikut yang dapat penulis paparkan tentang pendulangan rupihan dari permainan game dari sudut pandang pemain.

Dalam ranah pemain (gamers) cara-cara mendapatakan uang diantaranya adalah dengan;

1. Penjualan level

2. Penjualan alat-alat kelengkapan perang/darah dan lain sebagainya

3. Penjualan item ketokohan (lakon)

4. Menjadi joki game

5. Menjadi tester game

6. Menyediakan bantuan bagi pemula dengan mengeklik akses masuk

7. Youtuber game

8. Mendapatkan mata uang emas yang dapat ditukar uang fisik

${ }^{16} \mathrm{https}$ // www.liputan6.com/tekno/read/822765/5-alasan-game-flappy-bird-ditarik-dari-peredaran ${ }^{17} \mathrm{https}$ // tekno.kompas.com/read/2017/11/20/13511077/pendapatan-candy-crush-naik-97-persencapai-rp-33-triliun

${ }^{18}$ Tentang valuasi, penjelasan singkatnya adalah; Nilai ekonomi dari sebuah bisnis.Apabila ada sebuah perusahaan yang mempunyai valuasi sekitar Rp 5 Triliun, maka siapa pun yang ingin mengakuisisi penuh perusahaan tersebut harus mempersiapkan uang minimal Rp 5 Triliun. Angka valuasi ini biasanya dijadikan acuan untuk mengukur seberapa besar potensi bisnis sebuah perusahaan

${ }^{19} \mathrm{https}$ // www.cnnindonesia.com/teknologi/20170505090826-185-212445/diguyur-duit-dari-china-gojek-kini-bernilairp38-triliun 
Dari trend gain income ke delapan model game di atas adalah genre game online. Game online adalah game yang dimainkan menggunakan koneksi internet ${ }^{20}$.

Tidak seperti game offline yang membutuhkan download ketika ingin memulainya, game online dapat dimainkan secara langsung ketika ada koneksi internet ${ }^{21}$.Caramendapatkan uang juga beragam, berikut penjelasan ke delapan model gain income di atas;

Dari kedelapan aspek yang dapat diperjual belikan dapat dibedakan menjadi dua elemen;

\section{Terkait penjualan item seperti; level / ID, alat-alat kelengkapan perang, tokoh (lakon / armor), klik link, dan uang emas.}

Penjualan level yang dimaksud bukan hanya menjual level secara utuh yang diperoleh seorang gamers hasil dari peramianannya, lebih detailnya adalah menjual ID pemain. Pemain / gamers biasanya menjual ID mereka mungkin karena sudah bosan atau tidak memiliki waktu luang untuk memainkan game lagi, sedangkan bagi pembeli biasanya merupakan pemain baru yang ingin cepat mengakses level tertinggi, atau ada pula yang membeli ID karena ingin menyamakan pasukan (armor) dengan kelompok-kelompok atas, agar dapat bersaing dalam peperangan. Contoh game seperti ini adalah Clash OF Clans atau disingkat; COC, Dota 2, dan lain sebagainya. Harga ID coc yang ditawarkan cukup beragam, molai Rp 50.000,sampai Rp 1.000.000,- ke atas. Sistemasi penjualannya juga bermacam-macam, ada yang melalu start up semisal TokoPedia, BukaLapak, dan lain sebagainya, ada yang menjualnyamelalui cod (cash on delivery) / tunai.

Jual beli item persenjataan, jual beli barang-barang ini lain dengan penjualan ID. Jika ID diibaratkan peralihan kuasa penuh ID kepada pihak ke dua (pembeli), kalau penjualan part persenjataan berupa tembak, baju perang, darah, dan lain sebagainya yang berfungsi sebagai

\footnotetext{
${ }^{20}$ Sederhananya, bermain game online harus terkoneksi dengan server game yang sudah disediakan, jika game tidak memiliki server di Indonesia, maka game menggunakan server dari luar negeri, sebaliknya jika server ada di Indonesia, cukum menggunakan server lokal tanpa harus terkoneksi dengan server yang ada di luar negeri. Dan tentu dari segi biaya lebih murah menggunakan server yang ada di Indonesia daripada di luar negeri. Wahana Komputer, Membangun Warnet dan Game Center Sendiri,(Yogyakarta : Andi Offset, 2010) 111 dan 112 ${ }^{21}$ Dalam buku; Jubilee Enterprise, 20 Bisnis IT Dari Hobi Menjadi Rejeki, Jakarta : Elex Media Computindo,
}

Gramedia, 2010), 11. dijelaskan; "Para pemilik game online harus menyadari bahwa bisnis ini mendapat tantangan dari game offline semacam rental-rental PS. Namun salah satu yang menjadi daya tarik dari gameonline adalah tingkat persaingan yang real time yang bisa dilakukan oleh para game palyer secara serntak keberbagai belahan dunia". 
penunjang kekuatan perang. Jual beli part perang ${ }^{22}$ ini juga ada pada game Clash Of Clans, Dota2, Rising Force Online dan lain-lain.

Kemudian yang ketiga, dengan jenis game yang sama, namun item yang dijual berbeda, yang ketiga lebih kepada armor atau tokoh, atau sosok pahlawan pada game, seperti pada game Lost Saga, Dragon Nest, kesemua itu di jual dalam toko online seperti Juragancash.com ${ }^{23}$.

Selanjutnya yang agak unik adalah, pada genre game balap / Street Racing. Jadi ketika player menang balapan, lawan yang kalah akan mendapatkan link, jika lawan menge_klik link, maka pemenang secara otomatis dapat memperoleh sejumlah uang atas upah kemenangannya. Game ini adalah Street Racing $\mathrm{War}^{24}$.

Untuk penjualan uang emas juga dapat dijumpai salah satunya pada game Market Glory dan Golden Town. Adalah game yang ber_genre strategi, bagaimana pemain dapat mengatur strategi sedemikian rupa untuk membangun sebuah kota dan memperkuat bala tentara untuk bertarung menjamin keberlangsungan kota yang di bangun. Dari game ini pemain yang semakin tinggi levelnya akan menapatkan koin emas yang bisa ditukarkan dengan mata uang riil $^{25}$.

\section{a. Perolehan uang dengan cara; joki game, tester game, dan Youtuber game.}

Sebelum memabahas lebih detail tentang joki, tester, maupun youtuber game, ada baiknya penulis utarakan beberapa basic genre game-game yang ada, sebab dengan ini tulisan akan lebih mudah di fahami, basic game itu meliputi ${ }^{26}$; 1) RPG, 2) MMORPG, 3) MOBA, dan masing-masing basic game tersebut memiliki ciri khas tersendiri.

\section{a. RPG}

RPG merupakan singkatan dari Role Playing Game. Jenis game yang memerankan tokoh buatan dan menjalani serangkaian cerita tokoh. Singkatnya, game RPG adalah game yang memainkan peran tokoh tertentu untuk meraih menang dalam petualangannya.Contoh game nya; Final Fantasy XV, Sulkoden 2, The Witcher 3.

\footnotetext{
22https://dailysocial.id/post/kontroversi-bisnis-real-money-trading-dalam-game

${ }^{23}$ https://dailysocial.id/post/kontroversi-bisnis-real-money-trading-dalam-game

${ }^{24}$ https://www.juragancash.com/

${ }^{25}$ https://www.idntimes.com/tech/games/indra/gak-cuma-seru-8-games-ini-bisa-bikin-kamu-hasilkanduit-jutaan-rupiah/full

${ }^{26}$ Lihat ; https://www.kaskus.co.id/thread/5b278b4c9e74042f788b457e/5-cara-mendapatkan-uang-darigame-online/ dan https://www.idntimes.com/tech/games/indra/gak-cuma-seru-8-games-ini-bisa-bikinkamu-hasilkan-duit-jutaan-rupiah/full
} 


\section{b. MMORPG}

MMORPG merupakan singkatan dari Massively Multiplayer Online RolePlaying Game.Atau dengan kata lain adalah game yang memainkan tokoh buatandengan jalan peperangan secara bersama-sama (ramai-ramai). Sama seperti RPG tetapi MMORPG lebih seru karena membutuhkan banyak tokoh dalam permainan, yang menjadi serangkaian cerita.Contoh game nya; Ragnarok Online, Black Dessert Online, RF Online.

\section{c. MOBA}

MOBA singkatan dari Multiplayer Online Battle Arena. Adalah genre game yang tidak jauh seperti RPG maupun MMORPG tetetapi perbedaannya jika RPG player nya tunggal, sedangkan MMORPG multiplayer tetapi menjalankanserangkaian cerita bersama, tetapi kalau MOBA tidak menjalani serangkaian cerita bersama namun disediakan arena bertanding untuk melawan musuh-musuh lain secara online. Contoh game nya; Dota 2, Mobil Arena, Mobile Legends.

Dari sini awal mula tren mengumpulkan pundi-pundi uang melalui game. Bermain bersama-sama untuk memperoleh level yang tinggi, selepas itu dapat menjual item-item perolehan seperti alat-alat perang atau ketokohan, juga koin emasnya. Seperti dilansir oleh xdetik. $\operatorname{com}^{27}$ mengabarkan bahwa ada seorang pemuda yang jika dikumpulkan sedari awal ia bermain game hingga saat ini bekerja di sebuah perusahaan, telah menghabiskan kira-kira 300 juta rupiah.

Namun lain dengan yang didapatkan oleh pemain game yang mengikuti turnamenturnamen baik nasional maupun internasional, dalam situs kincir.com terdapat kira-kira sepuluh atlit eSport yang membawa pulang pundi-pundi rupiah, diantaranya ${ }^{28}$; Joshua Vega dengan timnya nxl, Riyan yang memiliki nickname "godNayr" pernah meraih pendapatandalam turnamen CrossFire tahun 2013 sebesar3.200 USD. Lihat juga situs esportsearnings.com ${ }^{29}$ Muhammad Rizky bersama tim Inyourdream memperoleh pendapatan 38.153,26 USD atau sekitar 562 Juta rupiah, Kevin Susanto dengan timnya XCCURATE memperoleh pendapatan 58.727,48 USD sekitar 865 Juta rupiah, dan Hansel dengan tim Bn'Te'T memperoleh pendapatan 93.906,51 USD sekitar 1.384 juta (satu milliar tiga ratus

\footnotetext{
${ }^{27}$ Lihat ; https://jalantikus.com/tips/perbedaan-moba-rpg-mmorpg

${ }^{28}$ https://kumparan.com/@kumparantech/q-and-a-melek-industri-game-indonesia-bersama-agate-studio

${ }^{29}$ https://x.detik.com/detail/intermeso/20180728/Sedapnya-Jadi-Joki-Game-Online/index.php
} 
delapan puluh empat juta rupiah), dihitung dengan nilai tukar Dollar terhadap Rupiah tahun ini (2018) sekitar 14.741,05 Rupiah / 1 Dollar USD. Dan salah satu turnamen saat ini menurut situs esprotsearnings.com; ada turnamen di bulan oktober 2018 dengan total hadiah sebesar 4.000.000 USD sekitar hampir 60 milliar rupiah, dengan pembagian hadiah pertama memperoleh 1.500.000 USD (Rp 22.111.575.000), ke dua 1.000.000 USD (Rp 14.741.050.000), ke tiga 750.000 USD (Rp 11.055.787.500)

Jadi singkatnya, permainan game online saat ini telah memiliki domainnya sendiri, perputaran uang pada game online di Indonesia juga tidak dapat dibilang kecil, pada portal berita kumparan.com ${ }^{30}$ di tahun 2015 perputaran uang game online mencapai 321 juta Dollar AS atau sekitar Rp 4,732 Triliun, dan di prediksi akan naik sebesar 841 juta Dollar AS sekitar 12,398 Triliun di tahun 2017. Namun menurut berita kurva.com ${ }^{31}$ pada tahun 2017 di Indonesia terdapat 43,7 juta pemain game atau nomor 16 terbaik di dunia, sedangkan total perputaran uang mencapai 880 juta Dollar AS atau mencapai Rp 13,38 Triliun. Surplus satu Triliun lebih dari prediksi awal 2015.

Game atau yang dikenal dengan eSport, pagelaran turnamennya banyakmemiliki kesamaan dengan turnamen cabang olah raga, seperti; sepak bola, voly, bulutangkis, renang, catur, pencak silat dan lain sebagainya, yang pemasukannya kebanyakan mengandalkan iklan produk-produk elekronik terkemuka yang ikut berpartisipasi dalam memberikan sponsor, iklan-iklan e-commerce, hingga penjualan tiket. Karena latihan menghadapi turnamen itu pula, profesi joki game di butuhkan.

Kemudian yang selanjutnya, profesi tester game. Profesi ini dilakukan oleh orangorang yang sangat profesional dalam dunia per_game an. Kebanyakan profesi ini dibuka oleh provider sendiri, atau developer game untuk mengetahui kecacatan produksi, atau untuk mengetahui detail grafis dari sebuah game, sebab ketika game yang diluncurkan memiliki cacat level atau desain grafis yang buruk tidak menutup kemungkinan akan rugi total.

Ke tiga youtuber game. Youtuber game dapat kita temui di situs-situs youtube, disitu banyak video tentang bagaimana memainkan salah satu game yang lagi hits saat ini dengan cara-cara profesional, atau berbentuk pengenalan publik dari game yang beru rilis (semacam trailer film). Pendapatan youtuber game dapat diperoleh dari bermacam-macam model; 1) dari iklan di layar youtube, 2) dari provider game. Pekerjaan ini seperti perusahaan Top Gear,

\footnotetext{
${ }^{30}$ https://www.kincir.com/game/pc-game/10-atlet-esports-indonesia-dengan-bayaran-termahal ${ }^{31} \mathrm{https} / /$ www.esportsearnings.com/countries/id
} 
perusahaan televisi yang banyak mengulas tentang kendaraan bermotor terutama mobil, baik mobil-mobil keluaran terbaru, atau tes komparasi mesin, eksterior dan interior mobil, kenyamanan berkendara, dan lain-lain.Lihat sebagian ulasan Top Gear di youtube ${ }^{32}$.

\section{GAME ONLINE DAN INDUSTRI 4,0}

Berbicara panjang lebar tentang game online tidak akan menuai maksud / "maqashid" dari game tersebut kecuali dibarengi dengan issue ekonomi yang baru, yakni industri 4,0. Oleh karena itu ada baiknya penulis paparkan secara singkat terlebih bagaiman industri 4,0 menjadi acuan pembangunan dunia era milenial.

Industri 4,0 adalah era industri berbasis $y b e r^{33}$.Maksudnya adalah kebijakan-kebijakan bisnis, baik pemasaran, mekanisme produksi, dan distribusi barang diatur secara sistemik dengan media online.Dengan demikian, industri-industri memiliki pergerakan yang aktif dan konstan secara terus menerus.Disamping itu, sistem yber juga diharapkan memperdekat manusia dengan kebutuhan-kebutuhannya. Dalam tataran distribusi produk seperti tokotoko online, jasa transport online, atau produk ciptaan seperti alat pantau kendaraan / GPS (Global Posisioning Sistem) dan lain sebagainya.

Industri 4,0 menghasilkan "pabrik cerdas". Didalam pabrik cerdas berstruktur moduler, sistem yyber fisik, menciptakan salinan dunia fisik secara virtual, dan membuat keputusan yang tidak terpusat, dengan kata lain lewat internet untuk segala keputusannya. Sistem yber fisik berkomunikasi dan bekerja sama individu satu dengan individu yang lain secara bersamaan, lewat komputasi awan (satelit) layanan internal dan lintas organisasi disediakan dan dimanfaatkan oleh berbagai pihak dalam rantai nilai. Lihat wikipedia.org ${ }^{34}$.

Menurut sumber data yang dapat dipertanggung jawabkan, awal mula istilah industri 4,0 adalah penerapan piranti cyber secara sistemik di pabrik yang ada di Jerman sekitar tahun $2012^{35}$. Sebuah "pabrik cerdas" dan canggih berbasis gyber yang menciptakan salinan dunia fisik ke virtual, dari hasil salinan dunia fisik ke dunia virtual tersebut menjadikan komunikasi bekerja antar individu lebih efisien baik secara kuantitas maupun kualitas, terintegrasi antara

\footnotetext{
${ }^{32 h t t p s: / / k u r v a . c o . i d / p e r p u t a r a n-u a n g-i n d u s t r i-g a m e-i n d o n e s i a-c a p a i-r p 1338-t r i l i u n / ~}$

${ }^{33}$ https://kurva.co.id/perputaran-uang-industri-game-indonesia-capai-rp1338-triliun/

${ }^{34}$ https://www.youtube.com/watch?v=3nC0gGRKxLc

${ }^{35}$ Asep N Mulyana, Pendekatan Ekonomi Dalam Penegakan Hukum Terhadap Kejahatan Korporasi, (Jakarta : PT Grasindo, 2018), 3. Menurut buku itu, revolusi industri 4,0 ditandai dengan cyberphysical system (mekanisme yang dikontrol oleh komputer berbasis logaritma), internet of things (perluasan manfaat konektivitas internet yang tersambung tanpa henti dan bio technology (penggunaan organisme hidup untuk mengembangkan produk baru.
}

73 Profit : Jurnal Kajian Ekonomi dan Perbankan 
pelaku dan alat produksi secara bersamaan real time. Seperti teknologi piranti game online yang menghubungkan pemain satu dengan pemain yang lain yang ada di luar negeri dalam satu waktu. Jika pada ranah pendidikan dikenal istilah multidisipliner antar rumpun ilmu keagamaan dengan umum.Dari sini terjadi jalinan koneksi yang secara substansial yang sangat milenialis.

Menurut sejarahnya ${ }^{36}$, awal mula istilah industri itu sendiri merupakan gerakan oposisi di paris yang tidak puas dengan politik kerjaan waktu itu, tokoh yang tekenal adalah Napoleon $^{37}$, kaum borjuis yang tidak puas itu mengajak untuk mengkrititsi kebijakankebijakan yang dirasa tidak adil saat itu, sehingga berdampak luas terhadap warga negara menjadi golongan-golongan / kelas, dalam taraf ekonomi. Dikotomi taraf kelas dalam maysarakat itu semakin menjadikan ketimpangan ekonomi yang berlebihan, gap antara si kaya dan si miskin semakin tajam, akibatnya yang kaya semakin kaya yang miskin semakin miskin.Dari sini masyarakat tidak punya harapan lagi selain revolusi.Maka dari sini awal mula kata-kata industri didengungkan ${ }^{38}$. Setalah revolusi industri yang ada di paris itu, bertumbuhlah rumah-rumah produksi seperti pabrik-pabrik, bome industri, yang mempekerjakan karyawan-karyawannya menggunakan alat-alat teknologi.

Awal mula teknologi industri menggunakan sistem kekuatan / power, seperti kuda, sapi, angin untuk memutar turbin dan lain sebagainya, kemudian bertambah dari sistem power ke sistem mekanikal, seperti munculnya teknologi mesin, motor-motor penggerak yang berbasis magnit yang dihubungkan dengan tembaga, hingga ahirnya menjadikan gerak, sejarah telah mencatat bagaimana jatuh bangunnya soichiro honda, sang pendiri honda, dan henri ford yang mendirikan ford motor company. Sistem mekanikal yang talah lama berlalu lalang di dunia internaisonal lambat lalun terasa belum sempurna, karena tidak ada sistem

\footnotetext{
${ }^{36}$ https://id.wikipedia.org/wiki/Industri_4.0

37https://www.bigopendata.eu/industry-4-0/ .Menurut website tersebut, awal mulanya adalah proposal kerja ke pemerintah Jerman sekitar tahun 2011 - 2012 yang dilakukan oleh beberapa perusahaan. Dengan proposal itu mereka menjelaskan basic Industri 4,0.

${ }^{38}$ Asem Mulyana, op cit, 03. Revolusi industri pertama terjadi sekitar tahun 1750 ketika ditemukannya mesin uap, sedangkan pada revolusi industri ke dua sektiar tahun 1850 ditandai dengan produksi massal dan revolusi industri ketiga sekitar tahun 1950 sebagai awal era komputer. Pada saat ini, yang biasa disebut revolusi industri keempat (industri 4,0) merupakan suatu era dimana produktivitas menjadi kata kunci, operasional excellent menjadi suatu keharusan dan konektivitas menjadi parameter dalam aktivitas bisnis dan transaksi ekonomi. Oleh karena itu, kecepaan, akurasi, dan konsistensi melalui kemampuan teknologi internet menjadi suatu keniscayaan pada abad revolusi industri 4,0.semakin pesat. James Watt sendiri memperoleh penemuan itu sekitar tahun 1780.Namun untuk memfokuskan tema, penulis sengaja tidak membahas mana yang lebih dahulu antara Inggris atau Perancis.
}

74 Profit : Jurnal Kajian Ekonomi dan Perbankan 
kontrol dari serangkaian kegiatan tersebut yang sistematis, seperti ketika untuk membuat laporan bulanan, harus mengumpulkan beribu-ribu kwitansi / nota pembelian, dapat dibayangkan bagaimana sulitnya orang-orang untuk mengumpulkan bukti-bukti fisik itu, apalagi selembar kertas bisa sobek, hangus, basah, dan yang lebih parah ketika tulisan sudah memudar.

Dari situ muncul komputer, teknologi perangkat lunak yang mampu membuat bukti fisik menajdi digital ${ }^{39}$, sehingga laporan-laporan penulisan yang asalnya beratus-ratus halaman dapat di singkat menggunakan satu layar monitor. Kehidupan manusia menjadi lebih efisien dari sebelum mengenal teknologi komputer dibanding dengan setelah mengenal teknologi komputer.Sistem tulis, audio, video telah tumbuh dengan pesat akibat teknologi komputerisasi.

Namun dari kecanggihan teknologi komputer tersebut manusia belum menemukan sambungan komunikasi yang interkoneksi antar manusia dari belahan bumi satu terhadap yang lain. Dari situlah kegelisahan-kegelisahan molai mucul, manusia ditantang untuk membuat teknologi baru yang interkoneksi dan trintegrasi terkait informasi dari individu satu terhadap individu yang lain ${ }^{40}$. Baru setelah dekade90 an manusia mengenal internet ${ }^{41}$, dan dari situ pula (dunia internet) manusia molai mengembangkan teknologi virtual.

\footnotetext{
${ }^{39}$ Seperti yang dijelaskan oleh buku Peta Jalan UKM 4,0 yang diberi kata pengantar oleh Hermawan Kertajaya; Edo Rinaldo, Christian M Marpaung, Aji Hogantara, Peta Jalan UKM 4,0 Profesional Produktif Kreatif danEntrepreneurial, MarkPlus, Inc. (Jakarta : Gramedi Pustaka Utama, 2017), 4. Dunia bisnis harus membangunkemampuan / competency secara profesional, dan ia (penulis buku itu) menyebut inti dari competency menjadi empat bagian; 1) Core Competencies (Adalah nilai-nilai sikap dan kepercayaan yang harus di miliki oleh individu-individu dalam berkerja dan harus diaplikasikan dalam melakukan tugas serta tanggung jawabnya sehari-hari), 2) People Competencies (Kemampuan personal yang dibangun untuk komunikasi dan berinteraksi antar individu), 3) Technical Competencies (Kemampuan teknikal, memiliki kemampuan yang bersifat teknis dan analisi terhadap produk, dan memberikan pelayanan yang baik), 4) Administrative Competencies (Adalah kemampuan yang bersifat admisnistratif / struktural yang dapat mendukung kegiatan operasional sehari-hari perusahaan). Hemat penulis, dengan empat elemen competency itu perusahaan akan memiliki operasional yang excellent, maka membangunnya harus terkoneksi dan terintegrasi dengan teknologi cyber. Dan yang oleh tulisandalam bukunya Asep Mulyana disebut industri 4,0 dengan tiga pendekatan; cyberphysical system, internet ofthings, dan bio technology.

${ }^{40}$ Yang dimaksud dengan pengintegrasian dan koneksitas informasi antar individu terlebih husus adalah yang terkait dengan pemasaran sebuah produk, sehingga perusahaan mencapai penjualan yang sempurna dan di atas rata-rata.Dalam bukunya Hermawan Kertajaya disitilahkan dengan Marketing Mix; Menentukan kompinasi produk, Harga, Serta Promosi yang sesuai dengan pemasaran. Hermawan Kertajaya dkk, Mark Plus on Strategy,
}

12 Tabun Perjalanan MarkPlus, Inc. (Jakarta : Gramedia Pustaka Utama, 2005), 21.

''Mengenai perkembangan Internet, lihat buku; Dony Ariyus, Pengantar Ilmu Kriptografi, Teori Analisis dan Implementasi, (Yogyakarta: CV Andi Offset, 2008), 5. 
Ketersambungan antara industri berbasis power, mekanikal, komputerisasi, dan gyber itulah yang disebut sebagai industri 4,0. Saat ini insustri 4,0 banyak dikaitkan dengan tema-tema kegiatan manusia yang berkonklusi dari berbagai manajemen, baik dunia bisnis, pendidikan, sistem pasar, dan semua kebijakan-kebijakan pemerintahan yang tidak menggunakan unsur teknologi industri 4,0 telah dianggap ketinggalan zaman ${ }^{42}$.

\section{TEORI AKAD DAN GAIN INCOME dari GAME ONLINE}

Dalam kitab Kifayatur Akhyar rukun dan syarat akad dijelaskan dengan ${ }^{43}$; Mengenai jual beli makruh, sesungguhnya jual beli makruh adalah jual beli yang berdasar suatu “paksaan”, bukan berarti barang / komoditinya yang makruh, seperti pengertian makruh dalam hukum taklifi ; wajib, sunnah, mandub, mubah, makruh dan haram. Tapi makruh dalam sistem/tatacara nya. Seperti yang dijelaskan dalam kitab Fikih Sunnab; ${ }^{44}$; Pada esensinya, Sayyid Sabiq mengatakan; jual beli secara makruh (tatacaranya) adalah diperbolehkan, seperti halnya seseorang yang dipaksa menjual rumahnya untuk perluasan jalan. Atau menjual barang yang disukai ( yang sebenarnya tidak ingin dijual) karena problem finansial rumah tangga, atau disebabkan untuk melunasi hutang-hutangnya.

\section{Penjelasannya adalah sebagai berikut;}

1. Tentang pernyataan mengikatkan diri (sighat al-'aqd) Dalam hal ini, adalah kesepakatan kedua belah pihak yang berkepentingan. Yakni kesepakatan antar pemain game itu sendiri. Dan sudah tentu keduanya saling mafhum atau memahami maksud dan tujuan antara penawaran dan permintaan terkait objek akad (seperti yang sudah dijelaskan di bab sebelumnya).

2. Tentang pihak-pihak yang ber akad (al-muta'aqidaini)

Pihak yang ber_akad adalah penjual maupun pembeli. Hampir dipastikanpembeli adalah juga pemain game yang sudah memiliki tujuan tertentu, seperti untuk upload di Youtube

42 Di dalam majalah Masyarakat Asean, oleh; Direktorat Jenderal Kerjasama ASEAN, Maysarakat Asean, Asean Goes Digital, Edisi 19 Agustus 2018, (Direktorat Jenderal Kerja Sama ASEAN Kementerian Luar Negeri, JL Taman Pejambon No 6, Jakarta Puasat), 19. Dalam tulisan disitu dijelaskan secara global Indonesia pada tahun 2017 meraih peringkat ke 36 dari 137 negara, naik $5 \%$ dari tahun yang lalu. Namun terkait infrastruktur teknologi Indonesia masih dinilai rendah (ranking 80), sedangkan ranking labor market (pasar tenaga kerja) juga masih di urutan ke 96. Lantas bagaimana penyelesaiannya.? Dikatakan; dalam menghadapi era industri 4,0 Indonesia menyiapkan fokus kepada lima industri utama yaitu; makanan dan miuman, tekstil, otomotif, elektronik dan kimia.

¿rmam Taqiyuddin Abi Bakr Muhammad Husni Ad-Damasyqi Asy- Syafi'i, tahqiq; Muhammad 'Audh Haikal, Kifayatul Akbyar, (Kairo, Dar As-Salam, 2005), 305 s/d 30

${ }^{44}$ Sayyid Sabiq, Fikih Sunnah, Jilid I - III (Kairo, Dar Al-Hadist, 2004), 908.

76 Profit : Jurnal Kajian Ekonomi dan Perbankan 
dengan demikian ia (pembeli) mengharapkan hasil dari iklan, atau untuk kepentingan lain semisal mengikuti kompetisi.

3. Tentang objek akad ( al-ma'qud alaihi), dengan mengacu kepada Kifayatul Akhyar oleh Imam Taqiyudin adalah sebagai berikut

a. Sesuatu yang menjadi objek akad atau al-ma'qud alaibi;

b. Barang harus bebas / terjaga

c. Barang harus bermanfaat

d. Barang harus di kuasa kan kepada penjual (penjual memiliki kuasa atas barang)

e. Barang dapat di serahkan (diserah terimakan

f. Barang dapat di ketahui / di mengerti)

4. Tidak diperbolehkannya jual beli barang-barang makruh, ada perbedaan dari kategorisasi makruh seperti yang dikatakan oleh Sayyid Sabiq dengan apa yang dikatakan oleh Muhammad Az-Zuhaily (syarah Mubadz-dzab). Dan jawaban ini sekaligus merangkum ke lima unsur yang perlu di hindari dari jual beli

Berbicara mengenai objek akad. Objek setidaknya harus memiliki 5 kriteria ;

1. Terbebas. Lihat makna thahir di kamus ${ }^{45}$; Yang terbebas / yang terjaga yang murni dan lain sebagainya.Singkatnya, thahir dapat dimaknai dengan; Barang yang diperjual belikan tidak boleh dalam kekuasaan pihak lain yang tanpa adanya peralihan kuasa, serta barang tidak dalam sengketa, dalam arti masih menunggu keputusan hakim

2. Objek harus bermanfaat; Berbicara manfaat, tentu sangat luas dan sangat terkait antara satu dengan yang lain, bisa jadi sesuatu tidak memiliki manfaat sama sekali karena tidak adanya sesuatu yang lain. Seperti adanyatikus yang mengakibatkan manfaat pada racun tikus.

3. Jika objek tidak bebas, dalam arti masih dalam sengketa, maka penjualannya harus menunggu keputusan hakim, sebagai penentu kuasa atas barang tersebut. Disini seperti seseorang yang memiliki kekayaan sedang ia memiliki hutang dan tidak mampu lagi membayar. Maka apabila putusan hakim mengabulkan pihak debitur (bank atau yang lain) menjual

4. secara lelang maupun non lelang, diperbolehkan.

¿oAttabik Ali dan Ahmad Zuhdi Muhdlor, Al-Asri (Kamus), (Yogyakarta, Pondok Pesantren Krapyak, Multikarya Grafika, 2004), 1221. 
5. Objek dapat diserahkan; Maksudnya, barang merupakan benda materi, jikaberbentuk jasa, maka jasa harus bermanfaat

6. Objek sebagai sesuatu yangmaklum, atau diketahui dan dimengerti khalayak umum

Sedangkan terkait objek yang makruh, selain penjelasan oleh Sayyaid Sabiq diatas, ada keterangan lain didalam kitab Muhadzdzab terkait makruh dikatakan ${ }^{46}$; Intinya; ketika objek makruh tersebut diperjual belikan tanpa ada keridha an, hukum jual beli menjadi batal. Namun apabila kedua belah pihak memutuskan berdasar keridha an masing-masing, jual beli dapat dibenarkan. Seperti sabdaRosululloh s.a.w; "Sesungguhnya jual beli itu berdasar atas keridha an".

Kesimpulan antara boleh dan tidaknya makruh dalam jual beli, tergantung illat (sebab) dari adanya jual beli. Jika sebab-sebab berjual beli seperti yang dikatakan Sayyid Sabiq; karena kebutuhan rumah tangga, atau kebutuhan orang tua, atau bahkan kebutuhan negara; seperti perluasan jalan dan lain-lain maka diperbolehkan. Akan tetapi pada esensinya, keduanya baik Sayyid Sabiq maupun Muhammad Az-Zuhaily mendasari jual beli tetap harus ada unsur ridha kedua belah pihak.

Selanjutnya poin A nomer $\mathbf{5}$ dari penjelasan di atas; objek adalah sesuatuyang maklum atau dapat diketahui. Objek / sesuatu yang diperdagangkan dalamgame saat ini telah menajdi sesuatu yang maklum adanya. Dan bukan lagi sesuatuyang absurd, atau tidak jelas ukurannya. Hampir semua orang yang memiliki akses / pernah bermain game mengetahuinya. Dan tentu bagi yang tidak pernah bermain tidaklah memiliki pengetahuan seperti apa ukuran dan kedalamannya permainan.

Lantas ada bantahan bahwa, kalau begitu, objek akad tidak maklum, dengan dalih hanya orang-orang tertentu saja yang mengetahui.? Jawabannya; bukankah dunia ini sangat luas.? Dan apakah ada seseorang yang mampu menguasai berbagai macam bidang pengetahuan sekaligus.? Seorang pakar teknik mesin mungkin saja ia buta atau tidak tahu sama sekali tentang sastra, atau seorang pakar fikih yang mungkin kurang faham matematika, atau soal-soal dalam hukum fisika. Apakah dengan demikian lantas seorang pakar fikih menyimpulkan sia-sia terhadap materi matematika atau fisika.?Tentu tidak.

¿"Muhammad Az -Zuhaily, Muhadzdzab, Jilid III, (Demaskus: Dar Al- Qalam, 1997), 
Semua ada ukurannya, tidak boleh di simpulkan dengan tergesa-gesa. Rosululloh s.a.w mengatakan ${ }^{47}$;Artinya; Kalian semua adalah pemimpin, dan kalian semua bertanggungjawab atas yang kalian pimpin. Dst.....

Namun untuk lebih jelasnya perlu menimbang manfaat dan mudharat dampak bermain game dari segi agama mupun sosial (dunia) ${ }^{48}$. Kemudian bagaimana mendefinisikan game, apakah game termasuk sesuatu yang sia-sia ataukah manfaat. Dengan demikian, kemaslahatan ummat akan tercapai.

Dampak bermain game bagi agama maupun sosial;

\section{Agama;}

Pertama, penulis sengaja membedakan agama dan sosial dengan tujuan untuk memudahkan pendevinisiannya, walaupun mungkin tidak ada peristiwa di dunia ini yang tidak ada sangkut pautnya dengan agama.

Pertama, agama menurut kultur budaya jawa disebut; ageman atau pegangan. Dalam

Al-Qur'an disebut $A d-D i n$ نيدا. Allah s.w.t berfirman;

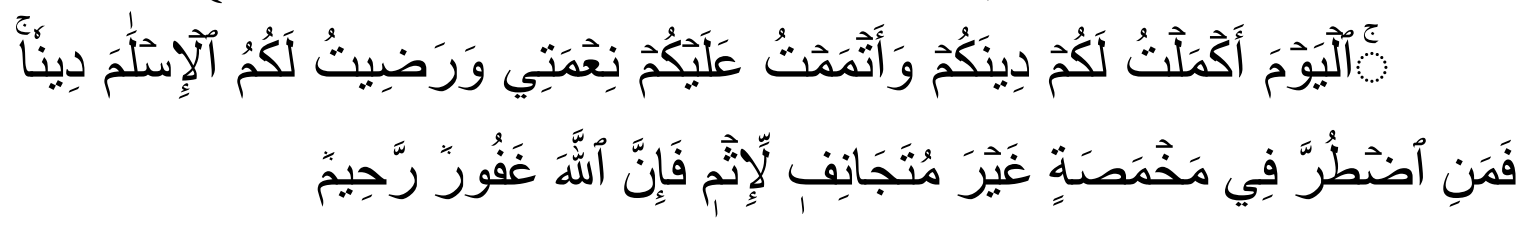

Artinya; .......Pada hari ini telah aku sempurnakan agamamu untuk.mu, dantelah aku cukupkan nikmat-Ku bagi mu, dan telah Aku ridai Islam sebagai agammu...... (Al-Maidah 03)

Singkatnya, agama adalah, sebuah petunjuk konkrit dari Tuhan untuk di dedikasikan kepada khalayak makhluk ${ }^{49}$.Terkhusus manusia, manusia memiliki hukum taklifi ${ }^{50}$ dikarenakan

${ }^{47}$ Hadist Bukhari No 893.Ibnu Hajar Al-‘Asqalani, Fathul Bari Syarah Shabih Bukhari, Jilid III, (Lebanon, Dar Al-Kutub Al-Ilmiyyah, 2005), 329. Lihat pula Hadist Muslim No 1829. Imam Abi Zakariya An-Nawawi, Syarah Shabih Muslim, Jilid 11-12, (Kairo, Maktabah Taufiqiyyah, t,th), 189. Dalam syarah shahih Muslimdikatakan; $A r$-Ra'i adalah yang menjaga, atau yang terpercaya, atau yang menegakkan kebenaran atas amanah yang dititipkan kepadanya. Maka apa-apa yang dipasrahkan kepadanya (di titipkan kepadanya suatu amanah), ia diharuskan berbuat adil baik agama maupun dunianya, dan apa-apa yang terkait keduanya. ${ }^{48}$ Seperti yang dikatakan Imam Nawawi dalam Syarah Shabih Muslim, Op Cit, 189.

${ }^{49}$ Makhluk yang lain, seperti hewan dan jin tidak memiliki kewajiban beragama seperti halnya manusia, akan tetapi mereka memiliki cara tersendiri dalam memuji Tuhan Penciptanya. Lihat Al-Qur'an surat Al-Isra' ayat 44 "Langit yang tujuh, bumi dan semua yang ada di dalamnya bertasbib kepada Allah.Dan tak ada sesuatu punmelainkan bertasbih dengan memuji_Nya, tetapi kamu sekalian tidak mengerti tasbib mereka.Sesunggubnya Dia adalah Maba Penyantun lagi Maba Pengampun.Dan hewan tidak memiliki ruh individual atau hanyamemiliki ruh kelompok, maka hewan bukanlah bentuk mikro dari yang makro (jagat alit jagat gede), dan esensi inilah yang membedakan manusia dengan hewan. Lihat buku; The Seat Of The Soul oleh Gary Zukav, yang diterjemahkan oleh; M Thoyibi, The Seat Of The Soul, Visi Baru tentang Takdir Manusia, (Jakarta: Pustaka Alvabet, 2006), 176 s/d 179. 
sistem "softwhare" yang dimiliki manusia berbeda dengan makhluk-makhluk lain, manusia memiliki nafsu, akal dan hati ${ }^{51}$.

Kedua, nilai esensi dari agama adalah mendekatkan diri kepada Tuhan.Jika sesuatu menjadikan jauhnya hamba kepada Tuhannya, maka sesuatu itu dilarang oleh agama. Sesuatu itu dapat berbentuk apa saja, kapan dan dimana saja. Membaca Al - Qur'an jika tidak dengan cara yang semestinya, atau dengan maksud mempermainkan atau hanya untuk tujuan gengsi, tidak dibenarkan menurut agama. Demikian dengan ibadah yang lain, walau bertujuan untuk mendekatkan diri kepada Tuhan, semisal shalat, jika tidak dilakukan sesuai syari'at yang tepat jadi batal shalatnya, semisal menambah rakaat shalat maktubah (shalat lima waktu), atau merubah waktu shalat yang telah ditentukan ${ }^{52}$. Dengan demikian, sesuatu itu bermanfaat atau tidak menurut agama tergantung person / individu bagaimana mengelaborasi perilakunya agar senantiasa terhubung dengan asas-asas ke_Tuhan_an. Singkatnya, penilaian sesuatu apakah termasuk bertujuan agama atau tidak, tergantung motivasinya.

\section{Sosial;}

Dalam pergaulan sosial oleh Allah sudah mengakatakan seperti apa yang ada dalam Al-Qur'an Surat Al-Ashr;Artinya; Demi massa. Sungguh, manusia berada dalam kerugian.Kecualiorang-orang yang beriman dan mengerjakan kebajikan serta saling menasehati untuk. kebenaran dan saling menasehati untuk kesabaran.(Al-Asr Ayat; 1,2,3)

Intinya adalah; Jika seseorang merasa benar sendiri, atau dalam pengertian lain; lupa diri, itulah titik awal kerugian manusia. Titik awal kerugian itu menjadi berlarut-larut jika tidak segera instropeksi atau evaluasi diri. Ranah sosial adalah tempat dimana individu bertemu dan berinteraksi dengan individu yang lain. Banyak suka duka yang menyelimuti.Diranah sosial itu dapat di ukur kecerdikan dan kepintaran seseorang dalam

\footnotetext{
50. Hukum taklif ialah; Ketentuan yang diperintahkan oleh Allah s.w.t sebagai suatu kewajiban. Adanya hukum taklif semisal perintah untuk shalat, karena ada ayat Qur'an yang berbunyi; Wa'aqimus Shalah, "Dan dirikanlah Shalat" (Al-Baqarah : 43). Contoh lain, kewajiban untuk berpuasa; Kutiba A'alaikumus Shiyam, "Diwajibkan atas kamu berpuasa" (Al-Baqarah : 183). Yang ke dua dinamakan Hukum Wad'i.Hukum wad'i ialah;kewajiban hamba beribadah kepada_Nya karena adanya sebab tertentu, seperti dalam ayat; Faman SyahidaMinkum As-syahra Fal Yasumbu, "Apabila kamu melihat hilal (bulan), maka berpuasalab" (Al-Baqarah 185), meilihat hilal menjadikan kewajiban hamba untuk berpuasa. Seperti juga dalam contoh; Walillabi "AlannasiHijjul Baiti Manistatha'a Ilaibi Sabila, "Dan (diantara) Kewajiban manusia terhadap Allah adalah melaksanakan ibadah Haji ke Baitullah, bagi orangorang yang mampu”, Kapan diwajibkannya manusia untukberhaji.? Ketika ia mampu secara finansial. Lihat Wahbah Zuhaily, Usul Fikih Al-Islamy, Jilid I (Demaskus, Dar Al-Fikr, 2005), 50 - 51

${ }^{51}$ Lebih lengkapnya lihat; Al-Ghazali, Ibya' Ulumuddin, Jilid 3, (Lebanon: Beirut, Dar Al-Fikr), 4.

${ }^{52}$ Semisal shalat subuh yang dua rakaat sengaja ditambahi menjadi empat atau lima rakaat misalnya. Jelas-jelas itu suatu yang dilarang dalam agama
} 
mengolah suatu masalah. Jika para pemain game itu tidak dapat mengontrol suatu masalah yang timbul dalam sosialnya. Berarti ia telah gagal, sebab apa kegagalannya.?Bisa jadi karena game. Tapi apakah memang demikian.?Belum dapat diketahui secara pasti. Jelasnya, ini merupakan mindset berfikir, ketika sesorang menganggap cin-cin yang dapat menyelamatkannya dari mara bahaya, maka ia sudah dihukumi kafir, karena sesungguhnya bukanlah cin-cin itu yang menyelamatkan ia dari mara bahaya, melainkan Allah, dan cin-cin hanya sebuah wasilah, tetap sang penentu adalah Allah, Tuhan yang tunggal.

\section{Terkait sesuatu yang sia-sia Allah s.w.t berfirman dalam Al-Qur'an ;}

Dalam surat Al-Imron ayat 85 dijelaskan yang artinya; .....Kehidupan dunia hanyalah kesenangan yang memperdaya..... (Al-Imron 185)

Secara general, pada prinsipnya semua yang ada di dunia ini adalah permainan dan senda gurau belaka, dalam arti, dapat melalaikan individu akan kehidupan di hari akhir. Maka tidak hanya game saja yang dapa melalaikan, belajar/menuntut ilmu; sekolah, kuliah, melakukan penelitian, jika tanpa motivasi adanya hari akhir, dapat melalaikan akhirat.

\section{Terkait sesuatu yang bermanfaat Allah s.w.t berfirman dalam Al-Qur'an ;}

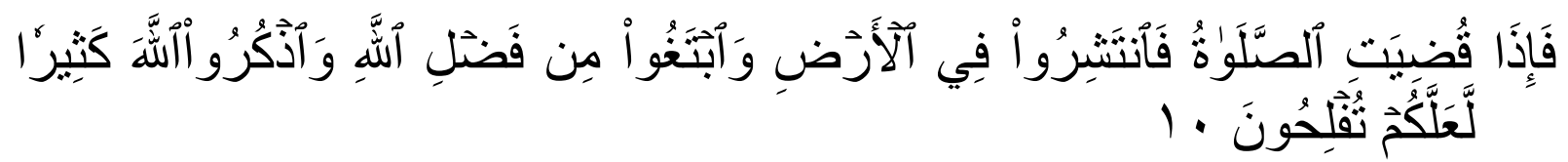

Artinya; Apabila telah dilaksanakan shalat, maka bertebaranlah kamu dimuka bumi dengan mencari karunia-karunia Allah, dan ingatlah Allah sebanyak-banyaknya supaya kamu beruntung.(AlJum'ah 10).

Secara tegas ayat ini mengatakan; carilah fadhilah-fadhilah Allah di muka bumi, entah seperti apa bentuk dan jenisnya, sebab ilmu Allah sangat luas, demikian juga faedah-faedah nya, maka sesuatu dapat berfaedah bagi kehidupan seseorang dunia dan akhirat mengikuti mindset masing-masing individu. Jika ia mampu mengungkapkan pemberian yang diperoleh dari bermain game dengan rasa syukur kepada Allah, maka menjadi baik.

Dan yang perlu diingat, dunia digital dibangun dengan kriptogarfi, yang terkait dengan pemecahan kode-kode rahasia digital.Orang yang ahli dalam melakukan pemecahan kode-kode rahasia digital dinamakan Kriptolog.Kriptografi merupakan ilmu trend abad ini sebab sangat terkait dengan e-comers. Dan sudah saatnya ummat muslim belajar lebih dalam terkait kriptografi, apalagi di era industri ke empat yang segala lini dituntut berbasis cyber. Analoginya, ketika pada zaman dahulu peradaban kota dibangun berdasar ilmu pertukangan, sehingga meninggalkan bangunan-bangunan besar yang prestisius. Saat ini sudah saatnya 
mekanisme tata kelola peradaban dibangun dengan berbasis yber yang menuntut penguasaan ilmu kriptografi. Maka game sebagai hasil rekayasa Kriptografi, tidak dapat dipandang sebelah mata, dengan pandangan sebagai fantasi semata ${ }^{53}$.

\section{KESIMPULAN}

Dunia saat ini telah berkembang sedemikian pesat berkat adanya skema Industri 4,0. Segaris dengan hal itu telah menciptakan rancangan bisnis baru, salah satunya adalah game online, bisnis yang murni berbasis gyber atau teknologi virtual yang dapat mempertemukan antar pemain dari mancanegara dalam multyplayer battlearena (arena pertempuran dengan banyak pemain). Oleh karena itu, Game denganbanyak pemain atau multiplayer game diprediksi tidak akan surut, bahkan akan berkembang dengan pesat.

Setelah dilakukan penelitian dengan pendekatan teori akad. Bisnis yang terkait dengan game online seperti yang telah dijelaskan dalam bab-bab sebelumnya, sesungguhnya secara akad tidak ditemukan kontradiksi karena subjek (Al-'Aqid) baik penjual maupun pembeli, atau objek barang (sesuatu yang di akad_i / ma'qud alaib) sudah jelas, subjek samasama memiliki tujuan tertentu, dan objek barang juga jelas dan terukur, bukan merupakan sesuatu yang tidak diketahui atau abstrak.

Oleh karena itu.Bisnis ini dapat dihukumi halal.Dan yang terpenting, unit usaha berbasis yyber adalah akuisisi keilmuan abad ini secara nyata dan riil. Ketika sebuah bangsa menguasai teknologi virtual, dapat dikatakan bangsa tersebut telah meloncat lebih maju dari bangsa-bangsa lain. Maka dapat diprediksi apabila Indonesia dapat menguasai gyber. At this point (cyber) the nations are currently competing.

\footnotetext{
53Singkatnya banyak objek yang dibangun dari prinsip Kriptografi atau perkomputeran berdasar alogaritma dan pemecahan sandi-sandi digital. Dalam buku Pengantar Ilmu Kriptografi antara lain yang terkait dengan; pemerintahan, organisasi-oraganisasi sosial, militer, bangk, pendidikan, transportasi, perdagangan, kriminalitas, industri dan lain-lain. lihat buku; Dony Ariyus, Pengantar Ilmu Kriptografi, Teori Analisis dan Implementasi, $\mathrm{Op}$ cit, 6.
} 


\section{DAFTAR PUSTAKA}

Noraini Ahmad, Menguatkan Ingatan, (Selangor Dalur Ehsan, Malaysia : LOHPRINT SDN BHD, 2004) 15.

Achmad Chodjim, Syaikh Siti Jenar danMakna Kematian, (Jakarta : PT Serambi Ilmu Semesta, 2014), 177.

Rulli Nasrullah, Teori Dan Riset Media Siber (CYBERMEDLA), Cet ke II (Jakarta : Prena Media Gorup, 2016), 148.

Buku Seri Panduan Lengkap Microsoft Windows 7, Diterbitkan atas kerjasama penerbit Andi Yogyakarta dengan MADCOMS, (Yogyakarta : CV Andi Offset, 2010),

Dimaz Ankaa Wijaya, Mengengal Bitcoin dan Cryptocurrency, (Medan : Puspantara Jalan Abadi, 2016),

Brian Kelly, The Bitcoin Big Bang How AleternativeCurriencies Are About to Change the World, Terj oleh Andri, The Bitcoin Big Bang, Bagaimana Mata UangAlternatif Mengubah Dunia, (Jakarta : PT Elex Media Komputindo, Gramedia, 2018), 168.,

Yuliandi Kusuma, Panduan Kreatif Fotografi Travel, (Jakarta : PT Grasindo, 2010)

Rendi Santoso, 10 Tahun Lagi Lo Mau Jadi Apa??, Jakarta : Elex Media Komputindo, Gramedia, 2014),

Hasballah Thaib, Hukum Akad dlam Fikih Islam dan Praktek di Bank Sistem Syari'ah, (Medan : Program Pascaasarjana Universitas Sumatera Utara, 2005)

Ibnu Taimiyyah, Majmu’ Fatawa, Jilid 28, (Saudi Arabia, 1938)

Hasan Ayyub, Fikih Al-Mu'amalat Al-Maliyyah fi Al-Islam, (Kairo: Dar As-Salam, 2006)

Ismail Nawawi, Perbankan Syariah (Issu-issu Manajemen Fiqh Mu'amalah Pengkayaan Teori Menuju

Praktik, (Surabaya : Vivpress, 2011)

Al-Qur'an dan terjemahnya, Wakaf dari Pelayan dua tanah Suci, Raja Fahd bin Abdul Aziz Al-Su'ud, Surat Al-Maidah ayat 1, hlm 156.

https://tekno.kompas.com/read/2014/02/06/1133198/Wow.Pembuat.Flappy.Bird.Raup.Rp.600.Ju ta.Sehari

https://www.smaato.com/guide-to-in-app-advertising/.

https://teknojurnal.com/apa-itu-in-app-purchase/

https:/ / www.liputan6.com/tekno/read/822765/5-alasan-game-flappy-bird-ditarik-dari-peredaran

https://tekno.kompas.com/read/2017/11/20/13511077/pendapatan-candy-crush-naik-97-

persen-capai-rp-33-triliun 
https://www.cnnindonesia.com/teknologi/20170505090826-185-212445/diguyur-duit-dari-chinagojek-kini-bernilai-rp38-triliun

Wahana Komputer, Membangun Warnet dan Game Center Sendiri,(Yogyakarta : Andi Offset, 2010) 111 dan 112

Jubilee Enterprise, 20 Bisnis IT Dari Hobi Menjadi Rejeki, (Jakarta : Elex Media Computindo,

Gramedia, 2010)

https:/ / dailysocial.id/post/kontroversi-bisnis-real-money-trading-dalam-game

https://dailysocial.id/post/kontroversi-bisnis-real-money-trading-dalam-game

https://www.juragancash.com/

https://www.idntimes.com/tech/games/indra/gak-cuma-seru-8-games-ini-bisa-bikin-kamuhasilkan-duit-jutaan-rupiah/full

https://www.kaskus.co.id/thread/5b278b4c9e74042f788b457e/5-cara-mendapatkan-uang-darigame-online/ dan https://www.idntimes.com/tech/games/indra/gak-cuma-seru-8-gamesini-bisa-bikin-kamu-hasilkan-duit-jutaan-rupiah/full

Lihat ; https://jalantikus.com/tips/perbedaan-moba-rpg-mmorpg

https://kumparan.com/@kumparantech/q-and-a-melek-industri-game-indonesia-bersama-agatestudio

https://x.detik.com/detail/intermeso/20180728/Sedapnya-Jadi-Joki-Game-Online/index.php

https://www.kincir.com/game/pc-game/10-atlet-esports-indonesia-dengan-bayaran-termahal

https://www.esportsearnings.com/countries/id

https://kurva.co.id/perputaran-uang-industri-game-indonesia-capai-rp1338-triliun/

https://www.youtube.com/watch?v=3nCogGRKxLc

Asep N Mulyana, Pendekatan Ekonomi Dalam Penegakan Hukum Terhadap Kejahatan Korporasi, Jakarta : PT Grasindo, 2018)

https://id.wikipedia.org/wiki/Industri_4.0

https://www.bigopendata.eu/industry-4-0/ .

Hermawan Kertajaya; Edo Rinaldo, Christian M Marpaung, Aji Hogantara, Peta Jalan UKM 4,0 Profesional Produktif Kreatif danEntrepreneurial, MarkPlus, Inc. (Jakarta : Gramedi Pustaka Utama, 2017)

Hermawan Kertajaya dkk, Mark Plus on Strategy, 12 Tahun Perjalanan MarkPlus, Inc. (Jakarta : Gramedia Pustaka Utama, 2005). 
Dony Ariyus, Pengantar Ilmu Kriptografi, Teori Analisis dan Implementasi, (Yogyakarta: CV Andi Offset, 2008),

Direktorat Jenderal Kerjasama ASEAN, Maysarakat Asean, Asean Goes Digital, Edisi 19 Agustus 2018, (Direktorat Jenderal Kerja Sama ASEAN Kementerian Luar Negeri, Jakarta Puasat)

Imam Taqiyuddin Abi Bakr Muhammad Husni Ad-Damasyqi Asy- Syafi'i, tahqiq; Muhammad 'Audh Haikal,

Kifayatul Akbyar, (Kairo, Dar As-Salam, 2005)

Sayyid Sabiq, Fikih Sunnah, Jilid I - III (Kairo, Dar Al-Hadist, 2004)

Attabik Ali dan Ahmad Zuhdi Muhdlor, Al-Asri (Kamus), (Yogyakarta, Pondok Pesantren

Krapyak, Multikarya Grafika, 2004)

Muhammad Az -Zuhaily, Mubadzdzab, Jilid III, (Demaskus: Dar Al- Qalam, 1997),

Ibnu Hajar Al-'Asqalani, Fathul Bari Syarah Shahih Bukhari, Jilid III, (Lebanon, Dar Al-Kutub AlIlmiyyah, 2005)

Imam Abi Zakariya An-Nawawi, Syarah Shabih Muslim, Jilid 11-12, (Kairo, Maktabah Taufiqiyyah, t,th),

Imam Nawawi dalam Syarah Shahih Muslim, Op Cit, 189.

The Seat Of The Soul oleh Gary Zukav, yang diterjemahkan oleh; M Thoyibi, The Seat Of The Soul, Visi Baru tentang Takdir Manusia, (Jakarta: Pustaka Alvabet, 2006)

Wahbah Zuhaily, Usul Fikih Al-Islamy, Jilid I (Demaskus, Dar Al-Fikr, 2005), 50 - 51

Al-Ghazali, Ibya' Ulumuddin, Jilid 3, (Lebanon: Beirut, Dar Al-Fikr), 4.

Dony Ariyus, Pengantar Ilmu Kriptografi, Teori Analisis dan Implementasi,Op cit, 6. 
